\title{
Method of railway line audit in terms of the condition of railway infrastructure
}

\author{
Magdalena Bartoś, and Piotr Gołębiowski ${ }^{*}$ \\ Warsaw University of Technology, Faculty of Transport, 00662 Warsaw, Poland
}

\begin{abstract}
The most important problems concerning the organization of railway traffic is continuous provision and systematic improvement the level of safety of services provided by railway transport enterprises. This safety results from many factors - including condition of the infrastructure, state of superstructure or the way of conducting railway traffic. This article covers railway infrastructure within its scope. In this regard include, among others take appropriate actions to monitor its condition. One of the methods may be the audit of the railway line in terms of infrastructure condition. The purpose of the article is to present the method of railway line audit in the area of infrastructure. The concept of railway line audit from the point of view of infrastructure status was defined in the paper. The audit method was presented along with the identification of problems that may occur as a result of the audit and suggestions for solutions to these problems. The presented method was verified for a selected railway line in Poland railway line No. 12 Skierniewice - Łuków. The possibilities of improving the condition of this line were proposed together with the estimation of the amount of expenditures necessary to make therefore and time gains achieved through improvement.
\end{abstract}

\section{Introduction}

Nowadays, rail transport is the safest type of land transport. The main factors influencing this fact should include, among others [1]:

- technical condition of the railway infrastructure,

- rolling stock technical condition [2, 3],

- technical condition of control command and signalling equipment [4],

- traffic organization [5],

- employees' competences,

- culture of public safety [6].

However, as in any transport mode, there may be a risk of a dangerous situation that can be caused by various factors. It can be classified into two groups:

- technical and organizational factors in which the railway system itself is the source of problems (e.g. bad condition of the track surface, inefficient rolling stock or control command and signalling equipment),

- external factors, caused by problems unrelated to the railway system (e.g. as a result of third-party activities or as a result of atmospheric phenomena).

In order to minimize the possibility of occurrence of any of the factors causing the emergence of danger, it is necessary to systematically carry out research of elements that may be exposed to their operation. The results of these research indicate the irregularities in the system. The main entities conducting research are infrastructure managers and railway undertakings. The mentioned units are responsible, among others, for safe operation of railway transport and railway traffic by exercising control over railway infrastructure. They have a huge impact on the risk in the railway system, which is why their representatives can quickly and effectively identify problems.

Research can be carried out in many ways. They include, among others, continuous control of individual units' data, analysis of the causes and effects of railway accidents [7-9], taking into account required safety standards and improving employee qualifications. Noteworthy is also the direct way of conducting research, i.e. inspection of individual elements of the railway transport system on the ground. A total of research methods to identify problems and where they occur can be described as an audit.

Audits can affect various areas of the railway transport system - including the organization of railway traffic $[10,11]$. Therefore, in order to properly organize railway traffic and constantly improve the quality of services provided, it is necessary to systematically check the condition of the railway line, i.e. carry out its audit. This process allows an in-depth analysis of problems threatening the safety of railway traffic, as well as identifying factors that negatively affect, among others, for the time of travel. The results of the audit also allow estimating the amount of expenditures necessary to improve the condition of the line.

The purpose of the article is to present the method of railway line audit in the area of infrastructure. The concept of railway line audit from the point of view of infrastructure status was defined in the paper. The audit method was presented along with the identification of 
problems that may occur as a result of the audit and suggestions for solutions to these problems. The presented method was verified for a selected railway line in Poland - railway line No. 12 Skierniewice - Łuków. The possibilities of improving the condition of this line were proposed together with the estimation of the amount of expenditures necessary to make therefore and time gains achieved through improvement.

\section{Audit of the railway line}

As mentioned in the introduction, the purpose of the article is to present the method of audit of the railway line from the point of view of the infrastructure condition. There is no explicit definition of railway line audit in the literature. One can only meet many definitions of the audit and the railway line.

In the literature, the concept of audit appears in a different context. The first of these concerns the verification of safety management systems (SMS), the implementation of which is required, among others, infrastructure managers [12-14]. The audits also concern activities related to technical maintenance of control command and signalling equipment [15]. Another context is the design of property security systems for travellers [16]. An important group of audits are also energy [14, 17, 18], organization [19], environmental [20-24] and financial audits [25]. Audit also plays a very important role in maintenance systems that are used on the railways [26-29]. It should be noted that systematic audits allow to maintain a safety culture in rail transport [7]. Interesting are tourist audits, whose area of interest is the functioning of railways in regions attractive for tourists [30].

Based on the considerations and the analysis of literature [31-40] the definition of railway line audit was developed. It reads as follows: railway line audit is a professional, independent and objective examination of the railway network element together with the necessary infrastructure intended for railway traffic conduction in order to determine whether its condition is correct due to the quantitative and qualitative criteria.

Quantitative criteria determining the condition of a railway line allow for a specific and actual characterization of a given quantity described in numbers, e.g. speed. On the other hand, the quality criteria are characterized by a lack of measurability and an independent character. These can include, among others, subjective assessment of passenger comfort.

Therefore, the audit of the railway line consists of characterizing the selected railway line in order to identify the problems encountered, and then on presenting proposals to solve them after the initial analysis of the time gains and the calculated amount of expenses related to the repair of identified problems. The introduced solutions are primarily aimed at improving railway traffic safety and railway infrastructure security.

Fig. 1 presents a general scheme of the audit of the railway line, which can be presented in the following form:
- STEP 1 - adoption of the value of the variable defining the direction of the railway line $k(k \in \mathbf{K})$ equal to 0 ( $\mathbf{K}-$ set of directions of the railway line),

- STEP 2 - increasing the value of the variable determining the direction of the railway line $k(k \in \mathbf{K})$ by 1 in order to consider all directions,

- STEP 3 - checking if the value $k(k \in \mathbf{K})$ determined in step 2 is less than or equal to the number of sets of directions; if so then go to step 4; otherwise the end of the algorithm's work is finished,

- STEP 4 - adoption of the value of the variable defining the problem number $n(n \in \mathbf{N})$ equal to $0(\mathbf{N}-$ set of problems regarding the state of infrastructure),

- STEP 5 - increasing the value of the problem number $n(n \in \mathbf{N})$ by 1 to consider all problems on the railway line,

- STEP 6 - checking if the value of $n(n \in \mathbf{N})$ determined in step 5 is less than or equal to the number of problems occurring on the railway line; if so, go to step 7; otherwise, go to step 2,

- STEP 7 - adoption of the value of the variable defining the kilometre value of the railway line $\mathrm{km}(\mathrm{km} \in \mathbf{K M})$ equal to 0 (KM - the set of kilometres constituting the railway line),

- STEP 8 - increasing the value of the variable determining the kilometre value of the railway line $\mathrm{km}$ $(\mathrm{km} \in \mathbf{K M})$ by 0.001 in order to consider all the railway lines in succession,

- STEP 9 - checking if the value of $k m(k m \in \mathbf{K M})$ set in step 8 is less than or equal to the final kilometre value of the railway line; if so, you can go to step 10; otherwise, go to step 5,

- STEP 10 - checking if the problem $n(n \in \mathbf{N})$ found in a given kilometre on the railway $\mathrm{km}(\mathrm{km} \in \mathbf{K M})$ was found; if so, go to step 11, otherwise go to step 8,

- STEP 11 - record of a specific problem $n(n \in \mathbf{N})$ occurring at a specific kilometre on the railway $\mathrm{km}$ $(\mathrm{km} \in \mathbf{K M})$; then go back to step 5 .

In summary - the audit of the railway line consists in reviewing the railway line in each direction. For each problem identified in item 3 of the article, a railway line is viewed meter by meter if a given problem occurs.

\section{Identification of problems possible to occur as part of the audit of the railway line}

As mentioned in point 2 of the article, the audit of the railway line consists of a review of each meter of line for each direction of the railway line for the occurrence of individual problems. Therefore, in order to conduct an audit of the railway line, problems that may arise as a result of the audit should be identified.

Typical problems regarding the condition of the railway infrastructure that can be identified as part of the audit of the railway line are included in Table 1.

All the problems listed in Table 1 belong to the quality criteria for assessing the condition of railway infrastructure. The effect of most of them is to reduce the speed of trains, which is directly related to the lengthening their travel time. 


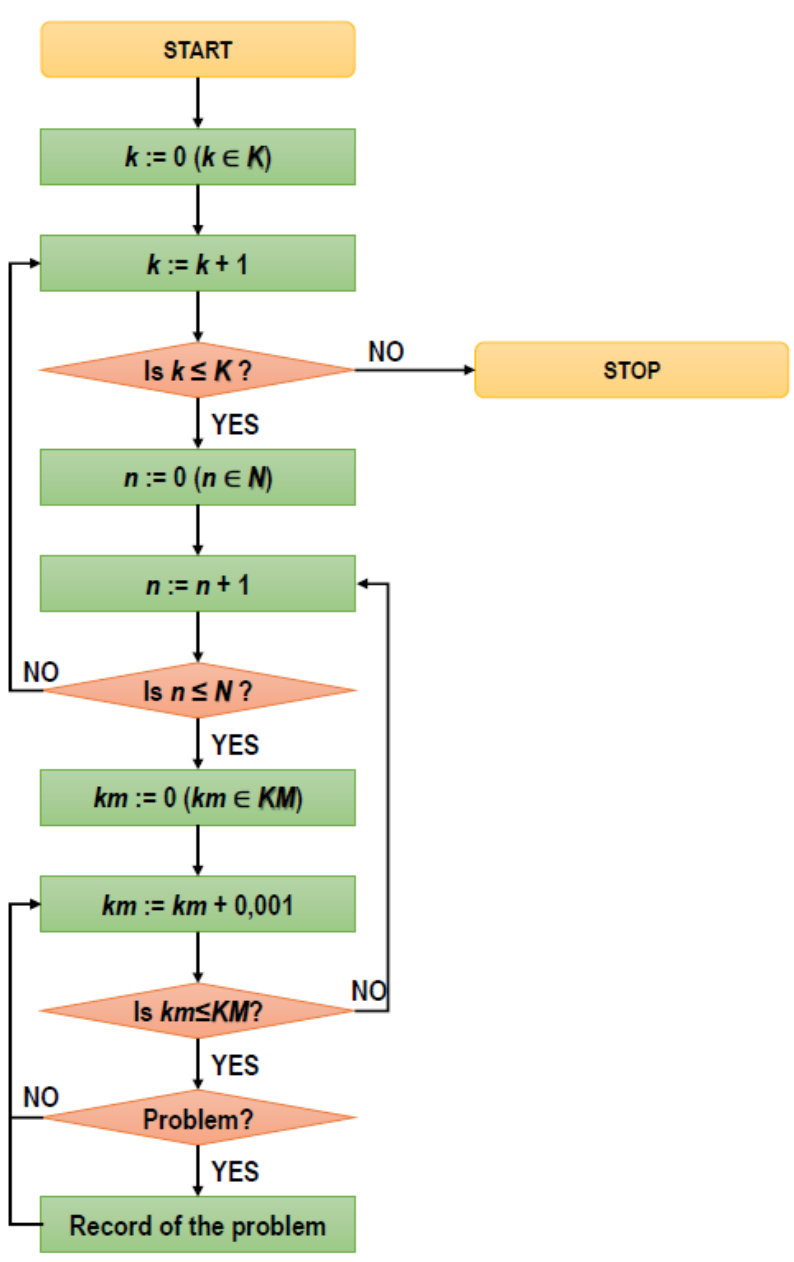

Fig. 1. The course of the railway line audit (source: own study)

Table 1. Typical problems regarding the condition of railway infrastructure (source: own study based on [35, 41, 42])

\begin{tabular}{|c|c|c|c|}
\hline No & Problem & $\begin{array}{l}\text { Nature of the } \\
\text { problem }\end{array}$ & $\begin{array}{c}\text { Impact on railway } \\
\text { traffic }\end{array}$ \\
\hline 1 & \multicolumn{3}{|c|}{ bad technical condition of the track } \\
\hline $\mathrm{a}$ & cracked rail & $\begin{array}{l}\text { damage of stretch of } \\
\text { rails }\end{array}$ & $\begin{array}{l}\text { reducing train speed } \\
\text { or closing the track } \\
\text { and stopping train } \\
\text { traffic }\end{array}$ \\
\hline $\mathrm{b}$ & $\begin{array}{l}\text { crookedness } \\
\text { and } \\
\text { deformation of } \\
\text { the track }\end{array}$ & $\begin{array}{l}\text { deviations from the } \\
\text { correct track } \\
\text { construction system } \\
\text { with the possibility of } \\
\text { continuously } \\
\text { increasing the } \\
\text { clearances }\end{array}$ & $\begin{array}{l}\text { reducing train speed } \\
\text { or closing the track } \\
\text { and stopping train } \\
\text { traffic }\end{array}$ \\
\hline $\mathrm{c}$ & $\begin{array}{c}\text { damaged } \\
\text { turnout }\end{array}$ & $\begin{array}{l}\text { damage to any of the } \\
\text { turnout elements, } \\
\text { incorrectly mounted } \\
\text { turnout on the switch } \\
\text { sleepers, defective } \\
\text { connection of } \\
\text { turnouts }\end{array}$ & $\begin{array}{l}\text { switching off the } \\
\text { turnout from } \\
\text { operation and } \\
\text { immobilizing the } \\
\text { switch in the } \\
\text { position for } \\
\text { authorized driving, } \\
\text { closing the turnout } \\
\text { for rolling stock } \\
\text { driving, limiting the } \\
\text { speed of trains }\end{array}$ \\
\hline $\mathrm{d}$ & $\begin{array}{l}\text { bad technical } \\
\text { condition of } \\
\text { the } \\
\text { substructure of } \\
\text { the track }\end{array}$ & $\begin{array}{l}\text { settlement of the } \\
\text { track, track bedding, } \\
\text { damage to slopes or } \\
\text { side ditches, } \\
\text { obstruction of } \\
\text { culverts }\end{array}$ & $\begin{array}{l}\text { reducing train speed } \\
\text { or closing the track } \\
\text { and stopping train } \\
\text { traffic }\end{array}$ \\
\hline
\end{tabular}

\begin{tabular}{|c|c|c|c|}
\hline No & Problem & $\begin{array}{l}\text { Nature of the } \\
\text { problem }\end{array}$ & $\begin{array}{l}\text { Impact on railway } \\
\text { traffic }\end{array}$ \\
\hline 2 & $\begin{array}{l}\text { sudden track } \\
\text { failure }\end{array}$ & unforeseen problem & $\begin{array}{l}\text { closing the track } \\
\text { and stopping train } \\
\text { traffic }\end{array}$ \\
\hline 3 & $\begin{array}{l}\text { wrong } \\
\text { geometric } \\
\text { layout of the } \\
\text { track }\end{array}$ & $\begin{array}{c}\text { too short straight } \\
\text { track section after the } \\
\text { obtuse crossing of } \\
\text { turnout, too small } \\
\text { radius of rounding } \\
\text { arch }\end{array}$ & $\begin{array}{l}\text { reducing the speed } \\
\text { of trains on a given } \\
\text { section }\end{array}$ \\
\hline 4 & $\begin{array}{l}\text { inadequate } \\
\text { ballast layer }\end{array}$ & $\begin{array}{c}\text { fast abrasion of } \\
\text { ballast, failure to } \\
\text { ensure the stability of } \\
\text { sleepers, } \\
\text { inappropriate surface } \\
\text { water drainage }\end{array}$ & $\begin{array}{c}\text { reducing train speed } \\
\text { or closing the track } \\
\text { and stopping train } \\
\text { traffic }\end{array}$ \\
\hline 5 & $\begin{array}{l}\text { turnout } \\
\text { technical } \\
\text { parameter }\end{array}$ & $\begin{array}{c}\text { wrongly selected } \\
\text { radius or slant of the } \\
\text { turnout }\end{array}$ & $\begin{array}{c}\text { reducing the speed } \\
\text { of trains on a given } \\
\text { turnout }\end{array}$ \\
\hline 6 & $\begin{array}{l}\text { small radius of } \\
\text { the arch }\end{array}$ & $\begin{array}{l}\text { radius of the arch not } \\
\text { adjusted to the } \\
\text { current speed }\end{array}$ & $\begin{array}{l}\text { reducing the speed } \\
\text { of trains on a given } \\
\text { arch }\end{array}$ \\
\hline 7 & $\begin{array}{l}\text { damaged } \\
\text { control } \\
\text { command and } \\
\text { signalling } \\
\text { equipment and } \\
\text { systems }\end{array}$ & $\begin{array}{l}\text { damage of track side } \\
\text { and linear equipment }\end{array}$ & $\begin{array}{l}\text { reducing the } \\
\text { frequency of trains } \\
\text { on the open line, } \\
\text { reducing train } \\
\text { speeds }\end{array}$ \\
\hline 8 & $\begin{array}{c}\text { damaged } \\
\text { traffic } \\
\text { protection } \\
\text { devices at } \\
\text { road-crossings } \\
\end{array}$ & $\begin{array}{l}\text { damage of track side } \\
\text { and linear equipment }\end{array}$ & $\begin{array}{l}\text { reducing the speed } \\
\text { of trains on a given } \\
\text { section }\end{array}$ \\
\hline 9 & & aged telecommunication & devices \\
\hline $\mathrm{a}$ & $\begin{array}{c}\text { faults in wired } \\
\text { communication } \\
\text { devices }\end{array}$ & $\begin{array}{l}\text { damage of track side } \\
\text { and linear equipment }\end{array}$ & $\begin{array}{l}\text { introduction of non- } \\
\text { interlocked block } \\
\text { and speed limit on } \\
\text { road-crossings up to } \\
20 \mathrm{~km} / \mathrm{h} \text {, extension } \\
\text { of dispatch of train } \\
\text { times at operating } \\
\text { control points }\end{array}$ \\
\hline $\mathrm{b}$ & $\begin{array}{c}\text { faults of radio } \\
\text { communication } \\
\text { devices }\end{array}$ & $\begin{array}{l}\text { damage of track side } \\
\text { and linear equipment }\end{array}$ & $\begin{array}{l}\text { temporary trains } \\
\text { announcing using } \\
\text { general } \\
\text { telecommunication } \\
\text { devices or mobile } \\
\text { telephony and } \\
\text { speed limit on road- } \\
\text { crossings up to } 20 \\
\mathrm{~km} / \mathrm{h} \text {, extension of } \\
\text { dispatch of train } \\
\text { times at operating } \\
\text { control points }\end{array}$ \\
\hline $\mathrm{c}$ & GSM-R faults & $\begin{array}{l}\text { damage of track side } \\
\text { and linear equipment }\end{array}$ & $\begin{array}{l}\text { reducing the speed } \\
\text { of trains, operating } \\
\text { of trains traffic } \\
\text { based on control } \\
\text { command and } \\
\text { signalling } \\
\text { equipment and } \\
\text { systems of the base } \\
\text { layer }\end{array}$ \\
\hline 10 & \multicolumn{3}{|c|}{ damaged energy devices } \\
\hline $\mathrm{a}$ & $\begin{array}{c}\text { damaged } \\
\text { telecommunica } \\
\text {-tions devices }\end{array}$ & $\begin{array}{l}\text { damage of track side } \\
\text { and linear equipment }\end{array}$ & $\begin{array}{c}\text { communication } \\
\text { break, impact on } \\
\text { traffic as for case } 9 \mathrm{a} \\
\text { or } 9 \mathrm{~b}\end{array}$ \\
\hline $\mathrm{b}$ & $\begin{array}{l}\text { interruptions in } \\
\text { the supply of } \\
\text { electricity }\end{array}$ & $\begin{array}{l}\text { lack of electricity in } \\
\text { the catenary }\end{array}$ & $\begin{array}{l}\text { total break in the } \\
\text { train traffic }\end{array}$ \\
\hline
\end{tabular}




\begin{tabular}{|c|c|c|c|}
\hline No & Problem & $\begin{array}{l}\text { Nature of the } \\
\text { problem }\end{array}$ & $\begin{array}{l}\text { Impact on railway } \\
\text { traffic }\end{array}$ \\
\hline c & catenary faults & $\begin{array}{l}\text { damage to the } \\
\text { catenary }\end{array}$ & $\begin{array}{l}\text { closing of the } \\
\text { traffic for electric } \\
\text { traction, running of } \\
\text { trains with diesel } \\
\text { traction, depending } \\
\text { on the scale of } \\
\text { damage - } \\
\text { conducting one } \\
\text { track two-way } \\
\text { traffic on the } \\
\text { second active track }\end{array}$ \\
\hline 11 & $\begin{array}{l}\text { carried out } \\
\text { track or road } \\
\text { works }\end{array}$ & $\begin{array}{l}\text { passing the train on } \\
\text { neighbouring track } \\
\text { with limited speed }\end{array}$ & $\begin{array}{l}\text { reducing train speed } \\
\text { or closing the track } \\
\text { and stopping train } \\
\text { traffic }\end{array}$ \\
\hline 12 & $\begin{array}{l}\text { exceeded the } \\
\text { exposure factor } \\
\text { on the road- } \\
\text { crossing }\end{array}$ & $\begin{array}{l}\text { too high road traffic } \\
\text { volume in relation to } \\
\text { the volume of } \\
\text { railway traffic }\end{array}$ & $\begin{array}{l}\text { reduction of train } \\
\text { speeds to } 20 \mathrm{~km} / \mathrm{h} \\
\text { at road-crossing }\end{array}$ \\
\hline 13 & $\begin{array}{l}\text { damage of } \\
\text { complete long- } \\
\text { arm gate }\end{array}$ & device failure & $\begin{array}{l}\text { reduction of train } \\
\text { speeds to } 20 \mathrm{~km} / \mathrm{h} \\
\text { at road-crossing }\end{array}$ \\
\hline 14 & $\begin{array}{l}\text { no service at } \\
\text { road-crossings }\end{array}$ & $\begin{array}{l}\text { no devices on the } \\
\text { road-crossing or } \\
\text { devices are working } \\
\text { but they are not } \\
\text { running }\end{array}$ & $\begin{array}{l}\text { reduction of train } \\
\text { speeds to } 20 \mathrm{~km} / \mathrm{h} \\
\text { at road-crossing }\end{array}$ \\
\hline 15 & $\begin{array}{l}\text { temporary } \\
\text { crossing for } \\
\text { pedestrians }\end{array}$ & $\begin{array}{l}\text { pedestrian crossing in } \\
\text { the level of rails } \\
\text { created temporarily }\end{array}$ & $\begin{array}{l}\text { reduction of train } \\
\text { speeds to } 20 \mathrm{~km} / \mathrm{h} \\
\text { at pedestrian } \\
\text { crossing }\end{array}$ \\
\hline 16 & $\begin{array}{l}\text { occurrence of } \\
\text { crisis or } \\
\text { emergency } \\
\text { situations }\end{array}$ & unforeseen problems & $\begin{array}{l}\text { closing the track } \\
\text { and stopping the } \\
\text { trains traffic or } \\
\text { limiting the speed } \\
\text { of trains }\end{array}$ \\
\hline 17 & $\begin{array}{l}\text { no service at } \\
\text { the station }\end{array}$ & $\begin{array}{l}\text { closing the station for } \\
\text { technical and } \\
\text { operational needs, no } \\
\text { devices at the station } \\
\text { or devices are } \\
\text { working but are not } \\
\text { activated }\end{array}$ & $\begin{array}{l}\text { possible speed limit } \\
\text { for trains }\end{array}$ \\
\hline 18 & $\begin{array}{l}\text { the impact of } \\
\text { weather } \\
\text { conditions }\end{array}$ & $\begin{array}{l}\text { lowering the } \\
\text { embankment, } \\
\text { equipment failure due } \\
\text { to lightning, flood, } \\
\text { deformation etc. }\end{array}$ & $\begin{array}{l}\text { speed reduction or } \\
\text { temporary } \\
\text { suspension of train } \\
\text { movement until the } \\
\text { obstacle is removed }\end{array}$ \\
\hline
\end{tabular}

They cause delays in the running of passenger trains and longer delivery times for goods in freight traffic. As we know, one of the most important factors in choosing the type of transport for passengers and customers is travel time. In order to shorten it significantly, the maximum speed should be increased and the restrictions on the railway line should be eliminated.

\section{Determining ways to solve identified problems}

In railway transport, the solution of problems in the area of railway infrastructure can be twofold: revitalization or modernization of damaged elements. In order to abolish conditions on railway lines, the exact definition of both processes should be familiarized in order to correctly assign them to the listed problems.

Revitalization is a comprehensive and in-depth set of activities carried out to improve infrastructure conditions. The purpose of the performed activities is to restore the value and significance of degraded areas and objects (in the event of losing their original functions) to improve the economic, social and environmental situation.

Modernization [43] includes the execution of construction works in order to modernize and improve the infrastructure, striving to increase its utility value.

Therefore, revitalization, in contrast to modernization, which assumes improvement of the railway line parameters and increasing the permissible speed of trains, is only a reconstruction of the original condition of the railway line.

Problems on the railway lines identified in point 3 can be solved thanks to the proposed solutions contained in Table 2.

Table 2. Proposals for solutions of the problems related to the condition of railway infrastructure (source: own study)

\begin{tabular}{|c|c|c|c|c|}
\hline \multirow{2}{*}{ No } & \multirow{2}{*}{ Problem } & \multicolumn{3}{|c|}{ Proposals for solutions } \\
\hline & & Revitalization & Modernization & Others \\
\hline 1 & \multicolumn{4}{|c|}{ bad technical condition of the track } \\
\hline $\mathrm{a}$ & cracked rail & $\mathrm{X}$ & - & - \\
\hline $\mathrm{b}$ & $\begin{array}{l}\text { crookedness and } \\
\text { deformation of the } \\
\text { track }\end{array}$ & $\mathrm{X}$ & - & - \\
\hline $\mathrm{c}$ & damaged turnout & $\begin{array}{c}\text { X } \\
\text { (repair or } \\
\text { replacement } \\
\text { for the same) }\end{array}$ & $\begin{array}{c}\mathrm{X} \\
\text { (replacement } \\
\text { on a different } \\
\text { type) }\end{array}$ & - \\
\hline d & $\begin{array}{c}\text { bad technical } \\
\text { condition of the } \\
\text { substructure of the } \\
\text { track }\end{array}$ & $\mathrm{X}$ & - & - \\
\hline 2 & sudden track failure & $\mathrm{X}$ & - & - \\
\hline 3 & $\begin{array}{l}\text { wrong geometric } \\
\text { layout of the track }\end{array}$ & - & $\mathrm{X}$ & - \\
\hline 4 & $\begin{array}{c}\text { inadequate ballast } \\
\text { layer }\end{array}$ & $\mathrm{X}$ & - & - \\
\hline 5 & $\begin{array}{l}\text { turnout technical } \\
\text { parameter }\end{array}$ & - & $\mathrm{X}$ & - \\
\hline 6 & $\begin{array}{l}\text { small radius of the } \\
\text { arch }\end{array}$ & - & $\mathrm{X}$ & - \\
\hline 7 & $\begin{array}{l}\text { damaged control } \\
\text { command and } \\
\text { signalling } \\
\text { equipment and } \\
\text { systems }\end{array}$ & $\begin{array}{c}\mathrm{X} \\
\text { (repair) }\end{array}$ & $\begin{array}{c}\mathrm{X} \\
\text { (replacement) }\end{array}$ & - \\
\hline 8 & $\begin{array}{l}\text { damaged traffic } \\
\text { protection devices } \\
\text { at road-crossings }\end{array}$ & $\begin{array}{c}\mathrm{X} \\
\text { (repair) }\end{array}$ & $\begin{array}{c}\text { X } \\
\text { (replacement } \\
\text { or assembly of } \\
\text { new ones) }\end{array}$ & - \\
\hline 9 & damag & telecommunica & ions devices & \\
\hline $\mathrm{a}$ & $\begin{array}{c}\text { faults in wired } \\
\text { communication } \\
\text { devices }\end{array}$ & $\begin{array}{c}\mathrm{X} \\
\text { (repair) }\end{array}$ & $\begin{array}{c}\mathrm{X} \\
\text { (replacement } \\
\text { or assembly of } \\
\text { new ones) }\end{array}$ & - \\
\hline $\mathrm{b}$ & $\begin{array}{l}\text { faults of radio } \\
\text { communication } \\
\text { devices }\end{array}$ & $\begin{array}{c}\mathrm{X} \\
\text { (repair) }\end{array}$ & $\begin{array}{c}\mathrm{X} \\
\text { (replacement } \\
\text { or assembly of } \\
\text { new ones) }\end{array}$ & - \\
\hline $\mathrm{c}$ & GSM-R faults & $\begin{array}{c}\mathrm{X} \\
\text { (repair) }\end{array}$ & $\begin{array}{c}\mathrm{X} \\
\text { (replacement } \\
\text { or assembly of } \\
\text { new ones) }\end{array}$ & - \\
\hline
\end{tabular}




\begin{tabular}{|c|c|c|c|c|}
\hline \multirow{2}{*}{ No } & \multirow{2}{*}{ Problem } & \multicolumn{3}{|c|}{ Proposals for solutions } \\
\hline & & Revitalization & Modernization & Others \\
\hline 10 & \multicolumn{4}{|c|}{ damaged energy devices } \\
\hline $\mathrm{a}$ & $\begin{array}{c}\text { damaged } \\
\text { telecommunications } \\
\text { devices }\end{array}$ & $\begin{array}{c}\mathrm{X} \\
\text { (repair) }\end{array}$ & $\begin{array}{c}\mathrm{X} \\
\text { (replacement } \\
\text { or assembly of } \\
\text { new ones) }\end{array}$ & - \\
\hline $\mathrm{b}$ & $\begin{array}{l}\text { interruptions in the } \\
\text { supply of electricity }\end{array}$ & - & - & $\mathrm{X}$ \\
\hline $\mathrm{c}$ & catenary faults & $\begin{array}{c}\mathrm{X} \\
\text { (repair) }\end{array}$ & $\begin{array}{c}\text { X } \\
\text { (replacement } \\
\text { or assembly of } \\
\text { new ones) }\end{array}$ & - \\
\hline 11 & $\begin{array}{l}\text { carried out track or } \\
\text { road works }\end{array}$ & $\mathrm{X}$ & - & - \\
\hline 12 & $\begin{array}{l}\text { exceeded the } \\
\text { exposure factor on } \\
\text { the road-crossing }\end{array}$ & - & $\mathrm{X}$ & - \\
\hline 13 & $\begin{array}{c}\text { damage of } \\
\text { complete long-arm } \\
\text { gate }\end{array}$ & $\mathrm{X}$ & - & - \\
\hline 14 & $\begin{array}{l}\text { no service at road- } \\
\text { crossings }\end{array}$ & $\mathrm{X}$ & - & - \\
\hline 15 & $\begin{array}{l}\text { temporary crossing } \\
\text { for pedestrians }\end{array}$ & - & $\mathrm{X}$ & - \\
\hline 16 & $\begin{array}{l}\text { occurrence of crisis } \\
\text { or emergency } \\
\text { situations }\end{array}$ & $\begin{array}{c}\mathrm{X} \\
\text { (repair) }\end{array}$ & $\begin{array}{c}\mathrm{X} \\
\text { (replacement) }\end{array}$ & - \\
\hline 17 & $\begin{array}{l}\text { no service at the } \\
\text { station }\end{array}$ & $\mathrm{X}$ & - & - \\
\hline 18 & $\begin{array}{c}\text { the impact of } \\
\text { weather conditions }\end{array}$ & $\begin{array}{c}\mathrm{X} \\
\text { (repair) }\end{array}$ & $\begin{array}{c}\mathrm{X} \\
\text { (replacement) }\end{array}$ & - \\
\hline
\end{tabular}

Summing up the presented proposals for solutions of problems regarding the condition of infrastructure on railway lines, it can be noticed that for 25 problems, up to 19 can be eliminated by revitalization process. Comparing the cost of both processes, it can be seen that modernization consumes more costs. Thus, this means that the audit of the railway line leads to the identification of cheaper solutions of the constraints and difficulties. This factor is very important from the point of view of the infrastructure manager. Therefore, one of the main advantages of the method of solving defined problems proposed in the article is the need to make low financial outlays.

\section{Audit of railway line No. 12 in terms of infrastructure condition}

Based on the algorithm presented in point 2 of this article, an audit of the railway line No. 12 Skierniewice Łuków was carried out in order to find all the problems occurring on the open lines and operating offices. The line review was started from the odd track (from the Skierniewice station to the Luków station), subsequently searching for existing defects from the set of problems specified in point 3 in each kilometre.

As a result of the audit, identified problems were presented in Table 3 .
Table 3. Audit of the railway line No. 12 (source: own study based on [41])

\begin{tabular}{|c|c|c|c|}
\hline $\begin{array}{l}\text { Problem } \\
\text { no }\end{array}$ & $\begin{array}{l}\text { Problem } \\
\text { no from } \\
\text { table } 1\end{array}$ & Problem & $\begin{array}{c}\text { Place } \\
\text { where } \\
\text { problem } \\
\text { occurred } \\
{[\mathrm{km}]}\end{array}$ \\
\hline \multicolumn{4}{|c|}{ ODD DIRECTION } \\
\hline 1 & 12 & $\begin{array}{l}\text { exceeded the exposure factor } \\
\text { on the road-crossing }\end{array}$ & $\begin{array}{c}4,545- \\
4,555 \\
5,485- \\
5,495 \\
\end{array}$ \\
\hline 2 & 16 & $\begin{array}{l}\text { occurrence of crisis or } \\
\text { emergency situations (one- } \\
\text { track two-way traffic due to } \\
\text { closing of track No 2) }\end{array}$ & $\begin{array}{c}13,732- \\
26,199\end{array}$ \\
\hline 3 & 5 & $\begin{array}{l}\text { turnout technical parameter } \\
\text { (occurrence of scissors } \\
\text { crossing) }\end{array}$ & $\begin{array}{c}13,732 \\
47,963 \\
89,024 \\
97,350 \\
103,700\end{array}$ \\
\hline 4 & 11 & $\begin{array}{l}\text { carried out track or road } \\
\text { works }\end{array}$ & $\begin{array}{c}103,260- \\
103,650\end{array}$ \\
\hline 5 & 17 & no service at the station & $\begin{array}{c}109,300- \\
110,935 \\
141,176- \\
143,186\end{array}$ \\
\hline \multicolumn{4}{|c|}{ EVEN DIRECTION } \\
\hline 1 & 12 & $\begin{array}{l}\text { exceeded the exposure factor } \\
\text { on the road-crossing }\end{array}$ & $\begin{array}{c}4,545- \\
4,555 \\
5,485- \\
5,495\end{array}$ \\
\hline 6 & 2 & $\begin{array}{l}\text { sudden track failure (closing } \\
\text { the track due to landslide) }\end{array}$ & $\begin{array}{c}13,732- \\
26,199 \\
\end{array}$ \\
\hline 7 & $1 d$ & $\begin{array}{l}\text { bad technical condition of } \\
\text { the substructure of the track }\end{array}$ & $\begin{array}{c}25,780- \\
25,830 \\
\end{array}$ \\
\hline 8 & 4 & inadequate ballast layer & $\begin{array}{c}25,780- \\
25,830 \\
\end{array}$ \\
\hline 3 & 5 & $\begin{array}{l}\text { turnout technical parameter } \\
\text { (occurrence of scissors } \\
\text { crossing) }\end{array}$ & $\begin{array}{c}13,732 \\
47,963 \\
89,024 \\
97,350 \\
103,700\end{array}$ \\
\hline 4 & 11 & $\begin{array}{l}\text { carried out track or road } \\
\text { works }\end{array}$ & $\begin{array}{c}103,260- \\
103,650\end{array}$ \\
\hline 5 & 17 & no service at the station & $\begin{array}{c}109,300- \\
110,935 \\
141,176- \\
143,186\end{array}$ \\
\hline
\end{tabular}

\section{Proposals for solutions to identified problems for railway line No. 12}

The railway line audit method, proposed in the article, assumes that for the identified problems related to the railway line, a time profit and the amount of expenditure necessary to make their repair will be presented.

The biggest problem on the railway line No. 12 is the numerous limitations on the speed of train traffic associated with the poor condition of railway infrastructure along the entire length of the line. Therefore, the line parameters should be improved (to revitalize and/or modernize the line fragments in order to restore the construction speed). Additionally, at $\mathrm{km}$ 4,550 and 5,490 road-crossings should be reconstructed in order to raise their category from $\mathrm{D}$ to $\mathrm{B}$, because currently they are not equipped with appropriate train protection systems and devices. Changing the category means mounting on half-gate crossings and automatic 
traffic lights. Raising the category will allow for eliminating the problem related to the exposure factor.

Proposals for solutions of identified problems on the railway line no. 12 assume that all stations and passenger stops will be open for passenger trains. Therefore, the Parysów and Jedlanka stations located between Pilawa and Łuków should be opened for commercial and operational purposes. In addition, it is necessary to rebuild the platforms, which will be fully adapted to the needs of people with disabilities.

In addition, option 1 assumes the restoration of the construction speed over the entire line, the addition of necessary turnouts and the reconstruction of scissors crossings into single turnouts. In option 2 of the proposed solutions, all the changes introduced in the first option were taken into account and, additionally, the reconstruction of the closed track on the section Puszcza Mariańska - Mszczonów was assumed. Option 3 consists of the changes introduced in the second option and additionally the construction of the Góra Kalwaria Kępa Gliniecka open line with the railway bridge on the Vistula river for track 2. Additionally, it is necessary to reconstruct the track system at both exploitation points. The creation of a new facility will allow to shorten the time of trains' travel as a result of preventing the narrowing of the railway line from two-track to onetrack.

In order to accurately compare all options, calculations were made, thanks to which a time profit was obtained as well as the amount of necessary outlays for each option. Detailed results are provided in Table 4.

Table 4. Comparison of solution options (source: own study)

\begin{tabular}{|c|c|c|c|}
\hline \multirow{2}{*}{ Option } & \multicolumn{2}{|c|}{$\begin{array}{c}\text { Time profit from the current } \\
\text { state [min] }\end{array}$} & \multirow{2}{*}{$\begin{array}{c}\text { Outlays } \\
\text { [PLN] }\end{array}$} \\
\cline { 2 - 3 } & pass. trains & freight trains & \\
\hline option 1 & 70,81 & 84,99 & 231348243 \\
\hline option 2 & 75,09 & 90,95 & 238387256 \\
\hline option 3 & 76,02 & 93,62 & 293399611 \\
\hline
\end{tabular}

Summarizing the results of the calculation of the time profits and costs of all proposed variants relative to the current state of the railway line no. 12 , it can be concluded that the most advantageous in terms of time profit is option 2. Rejection of option 3 is due to the fact that there are too high costs of the proposed solutions in relation to the obtained time profit, in which the difference between option 2 is: $0.93 \mathrm{~min}$ for passenger trains and $2.67 \mathrm{~min}$ for freight trains.

\section{Summary and conclusions}

The audit allows to detect irregularities affecting the safety of railway traffic. Therefore, it is necessary to systematically control the railway lines in terms of their infrastructure condition in order to improve the provided services. The presented audit process in this article is based on a professional, independent and objective research of all elements of the railway network together with the necessary infrastructure in terms of quantitative and qualitative criteria, in order to check whether its condition is correct.

The condition of the infrastructure on the railway line No. 12 is bad. Many sections of the track surface are suitable for exchange, platforms and buildings at stations and passenger stops are devastated and overgrown, do not meet the requirements related to the transport of people. As a result of the audit, eight main problems affecting the existing limits of maximum speed of the trains were found on the railway line. These include: poor technical condition of the track, poor technical condition of the substructure of the track, sudden track failure (landslide), inadequate ballast layer, technical parameter of the turnout, track or road works, exceeded exposure factor at the road-crossing, closing of the station for technical and traffic needs.

The solution of the problems is possible by carrying out works allowing for raising the maximum speed to the construction speed. Three options have been developed, including the following: revitalization of railway tracks, construction of new platforms at passenger stations and stops, assembly of new turnouts, reconstruction of roadcrossings to upgrade their category and construction of a new single-track railway bridge on the Vistula River.

Currently, the route of the railway line no. 12 passenger trains overcome in $185,68 \mathrm{~min}$, and freight in $194,73 \mathrm{~min}$. Due to the changes introduced in individual options, the time of train travel has been significantly shortened by the following time:

- in option 1: passenger trains travel less by $70.81 \mathrm{~min}$, freight trains by $84.99 \mathrm{~min}$,

- in option 2: passenger trains travel less by $75.09 \mathrm{~min}$, freight trains by $90.95 \mathrm{~min}$,

- in option 3: passenger trains travel less by $76.02 \mathrm{~min}$, freight trains by $93.62 \mathrm{~min}$.

The basic costs at the level of works performed in the first option are estimated at PLN 231 million. This amount increases with the introduction of additional solutions: by PLN 7 million in option 2 and by PLN 62 million in option 3.

\section{References}

1. Urząd Transportu Kolejowego, Sprawozdanie ze stanu bezpieczeństwa ruchu kolejowego w 2016 r., Warszawa (2017)

2. M. Jacyna, P Gołębiowski., E. Szczepański, Proceedings of 19th International Scientific Conference Transport Means, 160 - 168 (2015)

3. A. Szeląg, Archives of Transport, 42(2), 75-83 (2017)

4. M. Jacyna, J. Kukulski, P. Gołębiowski, S. Jasiński, W. Wychowański, Journal of KONES Powertrain and Transport, 25(4), 533-546 (2018)

5. M. Jacyna, P. Gołębiowski, D. Pyza, Archives of Transport System Telematics, 11(1), 27-33 (2018)

6. R. Burdzik, B. Nowak, J. Rozmus, P. Słowiński, J. Pankiewicz, Archives of Transport, 44(4), 15-24 (2017) 
7. S. Clarke, Work \& stress, 12(3), 285-292 (1998)

8. J. Santos-Reyes, A. N. Beard, Civil Engineering and Environmental Systems, 20(1), 1-21 (2003)

9. J. Santos-Reyes, A. N. Beard, R. A. Smith, Proceedings of the Institution of Mechanical Engineers, Part F: Journal of Rail and Rapid Transit, 219(2), 47-65 (2005).

10. P. Gołębiowski, Logistics and Transport, 41(1), 91-100 (2019)

11. M. Jacyna, P. Gołębiowski, M. Krześniak, Scientific Journal of Silesian University of Technology. Series Transport, 96, 59-69 (2017)

12. R. Licow, F. Tomaszewski, Problemy Kolejnictwa, 171, 51-56 (2016)

13. M. Sitarz, TTS Technika Transportu Szynowego, 19(5-6), 56-61 (2012)

14. Z. Tian, S. Hillmansen, C. Roberts, P. Weston, N. Zhao, L. Chen, M. Chen, IET Electrical Systems in Transportation, 6(2), 41-49 (2016)

15. I. Jasiński, R. Białas, Zeszyty Naukowo-Techniczne Stowarzyszenia Inżynierów i Techników Komunikacji w Krakowie. Seria: Materiały Konferencyjne, 2(113), 227-239 (2017)

16. P. Królak, M. Sergot, M. Butlewski, Logistyka, 6, 14392-14399 (2014)

17. A. Grzegory, M. Kałas, Zeszyty NaukowoTechniczne Stowarzyszenia Inżynierów i Techników Komunikacji w Krakowie. Seria: Materiały Konferencyjne, 2(116), 165-170 (2018)

18. M. Jacyna, P. Gołębiowski, M. Urbaniak, Communications in Computer and Information Science: Tools of Transport Telematics, 199-210 (2016)

19. P. C. Cacciabue, Applied Ergonomics, 36(6), 709-718 (2005)

20. G. He, L. Zhang, Y. Lu, Environmental management, 44(3), 579-589 (2009)

21. I. Jacyna-Gołda, P. Gołębiowski, M. Izdebski, M. Kłodawski, R. Jachimowski, E. Szczepański, Journal of Vibroengineering, 19(7), 5627-5638 (2017)

22. I. Jacyna-Gołda, J. Żak, P. Gołębiowski, Archives of Transport, 32(4), 17-28 (2014)

23. M. Jacyna, M. Wasiak, K. Lewczuk, N. ChamierGliszczyński, T. Dąbrowski, Annual Set The Environment Protection, 20, 1007-1025 (2018)
24. J. Żak, P. Gołębiowski, K. Popiela, Transport Means 2018. Proceedings of 22nd International Scientific Conference. Part II, 950 - 955 (2018)

25. M. J. Broniewska, Zarządzanie i Finanse, 1(3), 75-90 (2013)

26. A. Boholm, Risk management, 12(4), 235-255 (2010)

27. J. R. Edwards, Accounting and Business Research, 16(63), 251-263 (1986)

28. M. Jabłoński, A. Jabłoński, Zeszyty NaukowoTechniczne Stowarzyszenia Inżynierów i Techników Komunikacji w Krakowie. Seria: Materiały Konferencyjne, 2(104), 183-196 (2014)

29. J. Kwaśnikowski, G. Gramza, Analiza wybranych zakłóceń w ruchu kolejowym, Poznań (2007)

30. M. Suszczewicz, Turystyka Kulturowa, 8, 20-40 (2015)

31. A. Herdan, Audyt wewnętrzny jako narzędzie wspomagajace efektywny nadzór korporacyjny w spótkach akcyjnych, Kraków (2009)

32. M. Jacyna, K. Lewczuk: Projektowanie systemów logistycznych, Warszawa (2016)

33. A. Jezierski, Logistyka, 5, 91-93 (2007)

34. W. Pająk, Zeszyty Naukowe Uniwersytetu Ekonomicznego w Krakowie, 774, 69-83 (2008)

35. PKP Polskie Linie Kolejowe S.A., Instrukcja o prowadzeniu ruchu pociagów Ir-1, Warszawa (2017)

36. Polskie Wydawnictwa Naukowe, Stownik języka polskiego, http://www.sjp.pwn.pl/

37. A. Skoczylas-Tworek: Audyt we wspótczesnej gospodarce rynkowej, Łódź (2015)

38. J. Sysak (red.), Drogi kolejowe, Warszawa (1982)

39. K. Towpik, Infrastruktura transportu kolejowego, Warszawa (2009)

40. J. Twaróg, Gospodarka Materiałowa i Logistyka, 7-8, 154-157 (1998)

41. PKP Polskie Linie Kolejowe S.A., Dodatek 2 do wewnętrznego rozkładu jazdy pociagów zawierająy wykaz ostrzeżeń stalych, Warszawa (2018)

42. PKP Polskie Linie Kolejowe S.A., Instrukcja o kontroli biegu pociagów pasażerskich $i$ towarowych Ir-14, Warszawa (2011)

43. J. Mikulski, K. Gorzelak, Archives of Transport, 44(4), 47-54 (2017) 